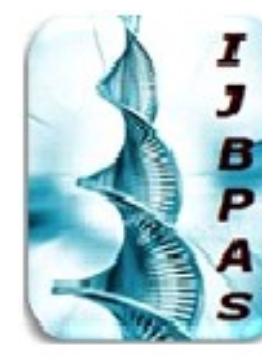

International Journal of Biology, Pharmacy and Allied Sciences (IJBPAS)

'A Bridge Betusen caboratory and Q Qender'

WwW.ibpas.com

\title{
ATYPICAL MANIFESTATION OF TYPHOID FEVER
}

\section{SARATH BHASKAR. $\mathbf{S}^{\mathbf{1}^{*}}$, PADMA.V ${ }^{2}$, KAVI.M.G ${ }^{3}$, SANDYA.P.C ${ }^{4}$, MURUGARAJ ${ }^{1}$, ABHILASH NAIR ${ }^{1}$, SAKETH RAMINENI ${ }^{1}$ AND KANNAN MEERA DEVI ${ }^{1}$}

1: Junior Resident, Department of General Medicine, Sree Balaji Medical College and Hospital, Chennai

2: Professor, Department of General Medicine, Sree Balaji Medical College and Hospital, Chennai 3: Assistant Professor, Department of General Medicine, Sree Balaji Medical College and Hospital,

\section{Chennai}

4: Senior Resident, Department of General Medicine, Sree Balaji Medical College and Hospital,

\section{Chennai}

*Corresponding Author: Dr. Sarath Bhaskar. S: E Mail: sarath_bhaskar@yahoo.com

Received 28 ${ }^{\text {th }}$ Dec. 2020; Revised $27^{\text {th }}$ Jan. 2021; Accepted $16^{\text {th }}$ Feb. 2021; Available online $1^{\text {st }}$ Oct. 2021

\section{https://doi.org/10.31032/IJBPAS/2021/10.10.5642}

\section{ABSTRACT}

Enteric fever is most commonly caused by Salmonella enteric Serovar typhi. Typhoid fever present as fever with classical gastrointestinal symptoms. Here a 30 year male who lives in a poor socio economic condition presented with chills, rigor and intermittent fever with bilateral parotid swelling. Initially he was treated for mumps viral infection. On further evaluation patient was diagnosed to have typhoid fever. Patient well responded to the antibiotic medication.

\section{Keyword: Fever, Parotid, Mumps, Infection, Atypical, Scrotal swelling}

\section{INTRODUCTION}

In lower socioeconomic group typhoid fever is one of the most common etiologies of fever. Salmonella typhi and salmonella paratyphi are the causative organism. It is transmitted by ingestion of contaminated food and water [1, 2]. The attack rate for typhoid fever is 1 in 30,000 travelers per month of travel to the developing world. It is an acute infection leading to bacteremia involving liver, spleen and lymph nodes. In poor compliance of treatment it may lead to multiorgan failure sepsis.

In general typhoid fever present with fever, toxaemia and gastrointestinal disturbances 
following intestinal haemorrhage and intestinal perforation results as complication if left untreated. Jaundice, abdominal lymphadenopathy, splenic and liver abscess, cholecystitis, pneumonitis, myocarditis, orhitis [3] are some of the rare unusual manifestations by typhoid fever. Here we are presenting a case of typhoid fever which presented with repeated fever spikes, bilateral parotid swelling and Left sided scrotal swelling.

\section{Case Report}

A 30 year old male with no known comorbidities presented with complaints of intermittent fever, throat pain, generalized body pain for 3 days, on examination patient was conscious, oriented to time, place and person and afebrile. BP- 110/800mmHg, PR$74 \mathrm{bpm}, \mathrm{SpO}_{2}-99 \%$ at room air. No skin hyperpigmentation or rashes. Chest sounds was normal and lung fields were clear. Per abdomen- soft, bowel sounds heard and no organomegaly. CNS examination revealed no focal neurologic defects. Patient was started on paracetamol 6th hourly for intermittent fever spikes. In evaluation complete blood count, peripheral smear for malarial parasite, typhoid, urine routine were found to be normal. Later patient developed swelling on the bilateral side of neck involving the parotid area on the left side more than the right side. Considering this presentations patient was provisionally diagnosed as mumps viral infection meanwhile Igm mumps antibody was sent for confirmation. On the course, symptoms were not settling and he developed left sided scrotal swelling with lower abdomen pain and high fever spikes with increased bilateral parotid swelling. Patient was shifted to ICU isolation for revaluation because of no clinical improvement. After that patient was started on intravenous antibiotics and antipyretics. Viral markers were sent for exclusion. His ultrasound abdomen and chest radiography were found to be normal. Doppler of bilateral testicular vessels showed mildly sluggish flow. Mumps test turned to be insignificant. $\operatorname{IgM}$ Typhi Dot IgM Antibody became positive, blood culture was sent for confirmation and rule out the other viral infections. Intravenous third generation cephalosporins were started; in between blood culture also confirmed the organism Salmonella typhi. Hence the final diagnosis was achieved and patient also responded well for the course of antibiotic treatment. After which patient was discharged with full recovery.

\section{DISCUSSION}

General manifestations of typhoid were well known and had a good prognosis on treatment $[4,5]$. But here these atypical manifestations delays the diagnosis and management of the patient. Here the patient presented with fever spikes, bilateral parotid enlargement and left sided scrotal swelling. Initially viral mumps infection was suspected because of above presentation. Later it was found it was to be the atypical presentation of typhoid by repeated evaluation. After which patient 
responded well for the antibiotic therapy and full recovery was obtained. At first week of illness there will be step ladder pattern of fever spikes associated with spleenomegaly and abdominal distension which is very common, in the third week patient will be toxic with significant weight loss. At this stage patient can develop toxaemia, myocarditis, intestinal haemorrhage and these complications may lead to multi organ failure. Later in the fourth week recovery begins, neurological and intestinal complications can manifest in surviving individuals. Some will be left as carries and they will be asymptomatic. Weakness and weight loss may last for months in recovery.

\section{CONCLUSION}

The variation of clinical symptoms occurs in typhoid fever for case to case. Repeated fever spikes with parotid and left sided scrotal enlargement will be considered as viral mumps infection provisionally but here it is diagnosed to be having typhoid fever which is very rare. Hence it is the atypical manifestation of typhoid fever in an individual from a lower socioeconomic group.

\section{REFERENCES}

[1] Bhan MK, Bahl R, Bhatnagar S. Typhoid and partyphoid fever. Lancet 2005; 366: 749-762.

[2] Bhutta ZA. Current concepts in the diagnosis and treatment of typhoid fever. BMJ 2006; 333: 78-82.
[3] Bhagwan, Bensal A, Bansal S. Atypical presentation of typhoid fever: a case report. API Med Update 2017; 2: 68-69.

[4] Dutta TK, Beeresha, Ghotekar LH. Atypical presentation of typhoid fever. J Postgrad Med., 2001; 47: 248

[5] Schiodt M, Dodd CL, Greenspan D, Daniels TE, Chernoff D, Hollander H, et al. Natural history of HIV-associated salivary gland disease. Oral Surg Oral Med Oral Pathol., 1992; 74: 326-331. 